\title{
PENDAMPINGAN PEMBUATAN MEDIA PEMBELAJARAN POWTOON BAGI GURU SEKOLAH DASAR GUGUS 1 KOTA BOGOR
}

\author{
Elly Sukmanasa ${ }^{1}$, Lina Novita ${ }^{1}$, Aries Maesya ${ }^{1}$ \\ ${ }^{1}$ Universitas Pakuan, Bogor, Indonesia \\ sukmanasaelly@gmail.com
}

\begin{abstract}
Abstrak: Pembelajaran abad 21 menuntut guru untuk memahami, mengenali, dan mampu menggunakan teknologi dengan baik. Sejalan dengan itu proses pembelajaran Kurikulum 2013 juga memerlukan kemampuan guru dalam bidang teknologi terutama dalam pembuatan media pembelajaran yang menarik. Salah satu permasalahan yang terjadi di sekolah Gugus 1 Kota Bogor adalah keterbatasan kemampuan guru dalam menggunakan media pembelajaran berbasis teknologi. Salah satu solusi dari permasalahan ini adalah pelaksanaan pendampingan pembuatan media Powtoon kepada guru-guru Sekolah Dasar (SD) melalui pemberian materi secara teoritis, praktek pembuatan Powtoon, sampai kepada evaluasinya. Tujuan program pengadian kepada masyarakat (PKM) ini adalah untuk melakukan pendampingan pembuatan media pembelajaran Powtoon pada pembelajaran kurikulum 2013 tematik kelas V SD Gugus 1 Kota Bogor. Metode yang digunakan adalah ceramah dan drill practice. Tahapan kegiatan diawali dengan penyampaian materi pentingnya media, pengenalan media Powtoon, dan dilanjutkan dengan drill practice yang mendorong peserta melakukan praktik pembuatan media Powtoon tersebut. Hasil pelatihan PKM ini menunjukkan sebanyak $91,2 \%$ peserta belum pernah mendengar tentang media Powtoon dan sebanyak $97,2 \%$ peserta belum pernah membuatnya dalam pembelajaran. Setelah dilaksanakannya PKM ini sebanyak 82,4\% peserta mampu membuat media Powtoon dengan baik. Kegiatan PKM ini efektif membantu guru untuk merancang pembelajaran berbasis teknologi khususnya media pembelajaran Powtoon.
\end{abstract}

Kata Kunci: pembelajaran abad 21, pendampingan, media Powtoon

\begin{abstract}
The 21st-century learning requires teachers to understand, recognize, and be able to use technology properly. In this case, the 2013 Curriculum (K13) learning process also requires teachers' technological ability to make attractive learning media. One of the problems found in the Cluster 1 Schools in Bogor is the limited ability of teachers to use technologybased learning media. The alternative to this problem is the training in making Powtoon to elementary school (SD) teachers through theoretical material delivery, practice, and evaluation. The purpose of the community service program is to provide assistance in making Powtoon for thematic learning in grade V Cluster 1 Bogor City. The method used was lecture and drill practice. It started with the presentation of the importance of media in learning, the introduction of Powtoon, and following by drill practice that encourages participants to practice the making of Powtoon. The results showed that $91.2 \%$ of participants had never heard of Powtoon media and $97.2 \%$ of participants had never made it in learning. After the implementation of PKM $82.4 \%$ of the participants were able to make Powtoon. This program is effective in helping teachers to design technology-based learning, especially Powtoon.
\end{abstract}

Keywords: $21^{\text {st }}$-century learning, accompaniment, Powtoon media

\section{Pendahuluan}

Pembelajaran merupakan suatu proses membelajarkan siswa. Pembelajaran sebagai suatu proses memiliki unsur-unsur yang saling berhubungan satu dengan lainnya. Hubungan unsur satu dengan lainnya akan menjadikan pembelajaran menjadi satu kesatuan yang utuh. Diantara unsur-unsur tersebut yang berkaitan dengan pelaksanaan pembelajaran adalah tujuan, proses pembelajaran terdiri dari materi ajar, metode, sumber belajar dan media 
pembelajaran, evaluasi pembelajaran serta pelaku pembelajaran, yaitu guru dan siswa. Namun terkadang proses pembelajaran sering mengalami masalah atau hambatan seperti kurikulum yang berganti atau berubah. Perubahan atau pergantian kurikulum ini dibuat dengan sengaja dengan tujuan untuk meningkatkan mutu atau kualitas pendidikan.

Pembelajaran yang aktif dapat terjadi dengan adanya bantuan media. Namun pada kenyataannya media yang ada kurang dimanfaatkan oleh guru. Hal ini merupakan salah satu faktor yang mengakibatkan kebosanan siswa pada saat belajar. Kondisi ini menjadi permasalahan yang terus berkelanjutan, karena guru kurang melakukan inovasi terutama dalam pengadaan media pembelajaran. Kondisi ini sama dengan permasalahan yang ditemukan pada penelitian (Novita, Windiyani, \& Fazriani, 2019) bahwa ketidakaktifan siswa disebabkan salah satunya oleh penggunaan media pembelajaran yang masih minim. Oleh sebab itu perlu adanya pengembangan media agar pembelajaran menjadi lebih baik.

Proses pelaksanaan pembelajaran dalam Kurikulum 2013 membutuhkan kompetensi bahwa seorang guru harus menguasai IT secara paripurna karena dimulai dari pembuatan perangkat pembelajaran pada kurikulum 2013 sangat erat kaitannya dengan penggunaaan IT. Demikian halnya dengan penggunaan media pembelajaran, guru dituntut untuk membuat media pembelajaran yang tidak hanya media berbasis non proyeksi tetapi dituntut pula berbasis proyeksi yang disesuaikan keadaan era globalisasi yang syarat dengan teknologi. Proses pendekatan pada pembelajaran Kurikulum 2013 untuk siswa Sekolah Dasar sangatlah komplek dan berkesinambungan yaitu tematik terpadu, pembelajaran yang berdasarkan tema, pendekatan Saintifik yang dikenal dengan pengalaman belajar pokok: menanya, mengumpulkan informasi, mengasosiasi, dan mengkomunikasikan. Demikian halnya dengan penilaian yang dilakukan sangat lebih luas dari pada kurikulum sebelumnya yaitu mencakup tiga ranah aspek kemampuan: afektif, kognitif, dan psikomotor. Itu semua merupakan upaya yang bertujuan untuk meningkatkan kulitas pendidikan di negara kita ini. Penelitian yang sudah dilakukan menunjukkan adanya permasalahan mengenai kurang aktifnya siswa (Ponza, Jampel, \& Sudarma, 2018; Novita, Windiyani, \& Fauziah, 2020; Andrianti, Susanti, \& Hudaidah, 2016). Penelitian lain yang dilakukan mengenai pentingnya media pembelajaran dengan metode eksperimen, menunjukkan perlu adanya pengembangan media pembelajaran sesuai dengan materi serta perlu dikembangkan dalam penerapan kurikulum 2013 (Awalia, Pamungkas, \& Alamsyah, 2019; Ariyanto, Kantun, \& Sukidin, 2018) Selanjutnya penggunaan media pembelajaran berbasis digital diteliti yang telah diteliti meninjau permasalahan mengenai siswa yang kurang aktif dalam pembelajaran, sehingga hasil belajar tidak sesuai dengan KKM (Sukmanasa, Windiyani, \& Novita, 2017; Fitriyani, 2019).

Kurang aktifnya siswa dapat diakibatkan dari rasa jenuh belajar dengan proses pembelajaran yang monoton dan komunikasi yang hanya dilakukan hanya satu arah. Dikatakan demikian karena guru hanya menerangkan atau hanya memberikan tugas mengisi lembar kerja siswa (LKS). Seperti diketahui pada buku pembelajaran kurikulum 2013 muatan materi pembelajaran cenderung sedikit, dapat mengakibatkan ketidakpahaman siswa atau bahkan guru itu sendiri (Nurdiansyah, Faisal, \& Sulkipani, 2018; Fajar, Riyana, \& Hanoum, 
2017). Guru masih bingung dengan materi ajar yang dapat dianggap kurang sehingga untuk menggunakan media yang memiliki tujuan untuk menarik minat atau motivasi siswa pun tidak dapat dilakukan. Ketidakpahaman guru terhadap kurikulum 2013 dan kurangnya penggunaan media pembelajaran dapat berdampak pada proses pembelajaran. Apabila kondisi tersebut terjadi, akibatnya siswa tidak memiliki keinginan untuk belajar, maka kualitas pembelajaran pun akan menurun.

Kurangnya minta siswa dalam belajar tidak terlepas dari peran guru dalam penggunaan media pada proses pembelajaran. Minat siswa dalam belajar akan baik jika didukung kreativitas guru dalam memanfaatkan media yang sesuai dengan materi pelajaran. Cara guru dalam menggunakan media juga harus sesuai dengan metode yang diterapkan. Hal tersebut disebabkan karena media yang dibuat belum tentu sesuai dengan materi yang akan diajarkan. Dengan demikian guru harus lebih kreatif dalam memanfaatkan dan mengembangkan media pembelajaran yang ada. Minat belajar siswa akan terlihat jika guru dapat memanfaatkan penggunaan media, sesuai dengan penelitian yang dilakukan, bahwa media pembelajaran dapat memberikan konstribusi dalam meningkatkan minat belajar siswa Tobamba, Siswono, \& Khaerudin, 2019).

Berdasarkan analisis situasi yaitu melaksanakan kunjungan ke lokasi tempat pengabdian kepada masyarakat, tim mengobservasi dan penyebaran kuisioner ke SD yang berada di lingkungan Gugus 1, dapat diidentifikasi permasalahan mitra antara lain: 1) keterbatasan fasilitas maupun sarana dan prasarana proses belajar; 2) keterbatasan sekolah dalam pengadaan media pembelajaran yang berbasis ilmu pengetahuan dan teknologi yang inovatif; 3) keterbatasan guru yang belum memiliki kompetensi dalam menggunakan media pembelajaran yang efektif; 4) proses pembelajaran harus menerapkan kurikulum 2013 dengan pendekatan saintifik, hal ini menuntut guru untuk menguasai IT dalam mendesain perangkat pembelajaran; 5) kemampuan dan penguasaan alternatif model-model pembelajaran inovatif yang harus diterapkan pada kurikulum 2013;6) kemampuan penguasaan guru Sekolah Dasar dalam mempersiapkan dan penggunaan media pembelajaran yang berbasis IT.

Berdasarkan hasil diskusi, permasalahan yang perlu segera dibenahi antara lain adalah: 1) mengajukan proposal ke walikota Bogor untuk membantu pengadaan sarana dan prasarana yang dibutuhkan oleh masing-masing sekolah; 2) menerapkan pendekatan Saintifik dan model-model pembelajarannya yaitu telah dilaksanakan pelatihan/workshop pembuatan perangkat pembelajaran Kurikulum 2013 dan latihan/workshop alternatif modelmodel pembelajaran yang inovatif baik oleh pemerintahan terkait maupun oleh tim dari program studi PGSD FKIP Universitas Pakuan.

Berdasarkan pemaparan di atas maka disepakati oleh tim pengusul dan mitra bahwa masalah utama yang menjadi prioritas yang perlu dilakukan berdasarkan pengkajian permasalahan, sampai saat ini yang belum teratasi permasalahannya. Ternyata dari berbagai masalah yang terungkap belum adanya Pendampingan Pembuatan Media Pembelajaran Powtoon Pada Pembelajaran Kurikulum 2013 untuk siswa Sekolah Dasar Kecamatan Bogor Tengah Kota Bogor. 
Penentuan prioritas permasalahan yang harus dicarikan penyelesaiannya dari awal dilakukan oleh Tim Pengusul yaitu: 1) melakukan pendampingan dan fasilitasi yang sinergi antara pihak sekolah dan komite sekolah untuk mendapat bantuan berupa alat/media pembelajaran; 2) melakukan pendampingan dan fasilitasi untuk mendapat bantuan berupa LCD dan Komputer; 3) melakukan pelatihan dan pendampingan pembuatan media pembelajaran berbasis ICT; 5) melakukan pelatihan pengenalan model-model pembelajaran.

Solusi yang ditawarkan untuk permasalahan kemampuan penguasaan guru Sekolah Dasar dalam mempersiapkan dan penggunaan media pembelajaran yang berbasis IT, yaitu melalui pendampingan pembuatan media pembelajaran Powtoon. Tujuan yang diharapkan dari pelatihan dan pendampingan adalah guru memiliki kemampuan dalam membuat media pembelajaran yang berbasis teknologi.

\section{Metode}

Pelaksanaan kegiatan pengabdian kepada masyarakat ini menggunakan metode melalui dua cara, yaitu dengan metode ceramah dan melalui latihan praktik (drill practice) pembuatan media pembelajaran berbasis Powtoon. Merode ceramah dilaksanakan dengan cara tim pengsusul mendatangi sekolah, yaitu SDN Pengadilan 2. Tujuan datang ke sekolah tersebut, yaitu untuk mensosialisasikan pelatihan pengembangan pembuatan media pembelajaran berbasis Powtoon. Kegiatan ceramah dilakukan mengingat masih banyak guru mengalami kesulitan dalam menyampaikan materi di kelasnya masing-masing pada saat pembelajaran. Berdasarkan pendapat (Sudjana, 2011), metode drill merupakan satu kegiatan melakukan hal yang sama, berulang-ulang secara sungguh-sungguh dengan tujuan untuk menyempurnakan suatu ketrampilan agar menjadi permanen.

Keberlanjutan program dilakukan dengan menjadikan PKM ini sebagai salah satu program unggulan pada Roadmap Pengabdian Masyarakat di tingkat program studi (khususnya Pendidikan Guru Sekolah Dasar dan program studi terkait sesuai dengan penerapan ipteks-nya), tingkat fakultas bahkan tingkat universitas. Pada roadmap tingkat universitas PKM ini menjadi bagian yang terintegrasi dengan program-program pengabdian masyarakat lainnya. PKM ini akan erat kaitannya dengan pembelajaran yang merupakan muatan perkuliahan pada Fakultas Keguruan dan ilmu pendidikan Unpak, yang direncanakan untuk jangka panjang hingga 20 tahun mendatang. Hal ini karena PKM didukung oleh penerapan media pembelajaran berupa TIK. Teknologi komputer tersebut dikemas menjadi salah satu media untuk mendukung penguatan keberlanjutan dan revitalisasi media pembelajaran. Media pembelajaran berbasis IT berupa Powtoon ini akan menarik dan menjadi motivasi peserta didik dalam belajar. Tujuan akhir dari hal ini adalah meningkatnya minat peserta didik sebagai generasi milineal penerus bangsa agar aktif dalam proses. Adapun langkah-langkah kegiatan pelatihan ini, yaitu:

1. Kegiatan pelatihan dilaksanakan selama 3 (tiga) hari mulai pukul 09.00-12.00 setiap hari. Pelaksanaan pendampingan pembuatan media pembelajaran Powtoon dilakukan dengan webinar, menginta kondisi pandemik Covid-19 
2. Tahap awal pelatihan mengulas pentingnya media pembelajaran, karena akan memotivasi siswa dalam belajar. Menjelaskan pengertian media pembelajaran Powtoon.

3. Tahap kedua pelatihan adalah melatih mitra dalam membuat media pembelajaran Powtoon, masuk ke akun Powtoon, memilih template, membuat slide materi, memilih animasi, menyimpan materi yang dibuat, mempublikasikannyaakan lebih baik.

4. Tahap akhir pelatihan adalah evaluasi. Kegiatan ini ditujukan sebagai indikator keberhasilan pelatihan.

5. Tahap evaluasi pada pelatihan ini berupa evaluasi jangka pendek yang dilakukan dengan webinar dan dilanjutkan dengan memberikan pengayaan berupa tugas pelatihan bagi peserta agar secara konsisten melengkapi dan menyempurnakan proses pembuatan media pembelajaran Powtoon.

6. Evaluasi dilakukan untuk jangka waktu 3 minggu ke depan, yang dilakukan setiap minggu. Pada minggu keempat tim PKM akan membuat forum pertemuan dengan agenda presentasi oleh mitra. Mitra menyampaikan hasil pembuatan media pembelajaran berbasis Powtoon.

\section{Hasil dan Pembahasan}

Pengabdian kepada Masyarakat ini bertujuan untuk melakukan pendampingan pembuatan media pembelajaran Powtoon pada pembelajaran kurikulum 2013 tematik untuk kelas V Sekolah Dasar Gugus 1 Kota Bogor. Kegiatan PKM ini difokuskan melalui proses diskusi dengan semua tim dan kedua mitra melalui tahapan sebagai berikut:

1. Pendampingan dan fasilitasi yang sinergi antara pihak sekolah dan komite sekolah untuk mendapat bantuan berupa alat/media pembelajaran.

Kedua mitra didampingi Tim PKM menyusun surat permohonan dan proposal untuk diskusi dengan kepala sekolah dan komite sekolah. Dengan demikian proposal ini diharapkan dapat dilengkapi dengan Surat Pernyataan Dukungan dari kepala sekolah dan komite sekolah. Kegiatan selanjutnya adalah pendampingan kegiatan diskusi dengan pihak tertuju. Indikator keberhasilan kegiatan ini adalah bantuan berupa sarana prasarana yang mendukung proses pembelajaran. Adanya bantuan berupa sarana prasarana, maka optimalisasi kegiatan pembelajaran akan semakin baik. Dengan demikian indikator keberhasilan kegiatan ini adalah adanya minimal 4 kegiatan kunjungan dari masyarakat.

2. Pelatihan dan Pendampingan pembuatan media pembelajaran Powtoon.

Pelaksanaan pelatihan dilakukan di tempat masing-masing. Hal ini terjadi karena adanya wabah corona yang menyebabkan tidak diperkenankannya melakukan acara seminar maupun pelatihan. Maka dirancanglah sebuah acara web seminar (webinar) bagi guruguru sekolah Dasar Gugus 1 Kota Bogor. 


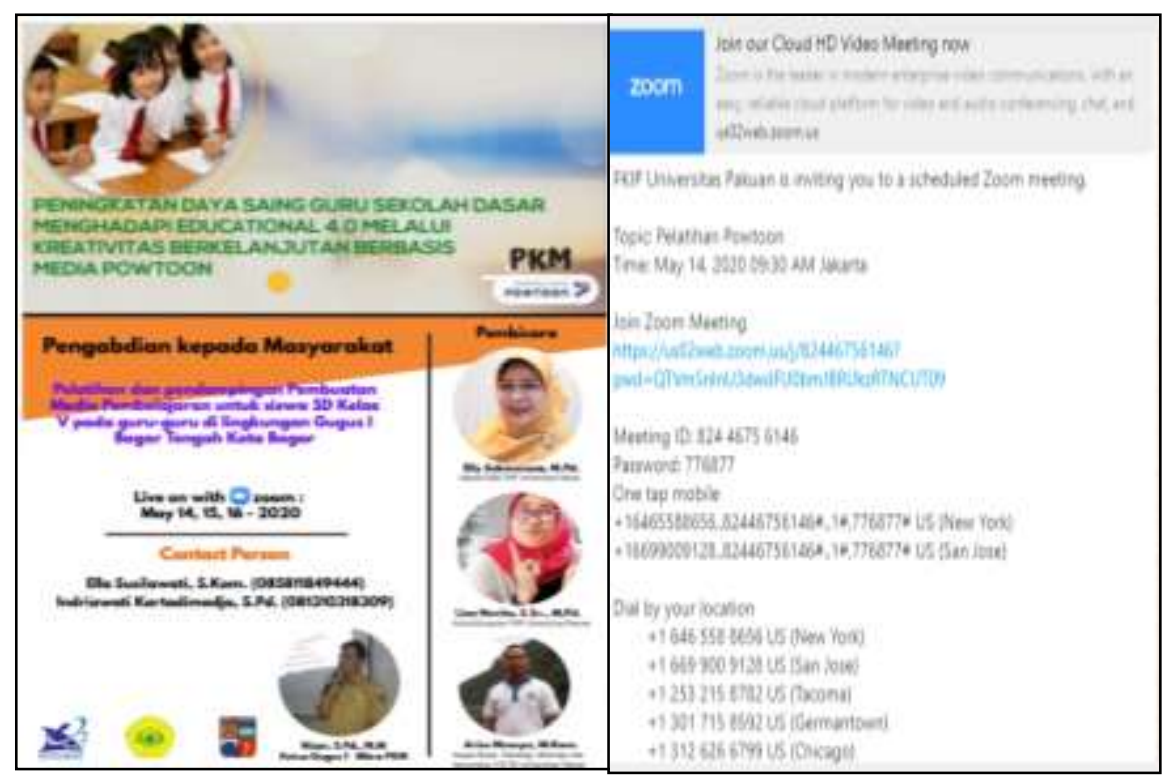

Gambar 1. Poster dan Format Undangan Acara Webinar PKM Pelatihan dan Pendampingan Pembuatan Media Powtoon bagi Guru SD Gugus 1 Kota Bogor

Gambar 1 di atas merupakan informasi yang diberikan oleh tim pendampingan kepada guru-guru yang ada di gugus 1 dan juga masyarakat luas. Selain itu juga merupakan penjelas akan pelaksanaan pendampingan yang dilakukan. Adapun rincian peserta pelatihan dapat dilihat dalam Tabel 1.

Tabel 1. Rincian Peserta yang Mengikuti Pelatihan

\begin{tabular}{cc}
\hline Nama Sekolah & Jumlah Peserta \\
\hline SDN Pengadilan 1 & 5 \\
SDN Pengadilan 2 & 9 \\
SDN Pengadilan 3 & 5 \\
SDN Pengadilan 5 & 12 \\
SDN Perwira & 3 \\
\hline Jumlah & 34 \\
\hline
\end{tabular}

Pelatihan ini mewajibkan setiap peserta webinar diharuskan mempersiapkan laptop atau komputer untuk mengikuti pelatihan ini. Materi pelatihan berupa pembuatan peta konsep dari kurikulum 2013 dan selanjutnya pembuatan desain atau rancangan materi yang nantinya dimasukkan pada media Powtoon. Pada kegiatan praktik mitra diwajibkan untuk mendesain dan membuat materi sesuai dengan tema pelajaran pada kurikulum 2013. Materi pelajaran disesuaikan dengan tema pada buku guru dan buku siswa. Setelah itu akan diberikan tutorial cara membuat media pembelajaran memanfaatakan teknologi komputer dengan aplikasi Microsoft Office. Gambar 2 menjelaskan bagian dari materi pada pendampingan. Materi pembuatan media pembelajaran berbasis Powtoon ini diawali dengan pentingnya penggunaan media dalam pembelajaran. Materi tersampaikan dengan baik dan dapat dipahami oleh peserta. 


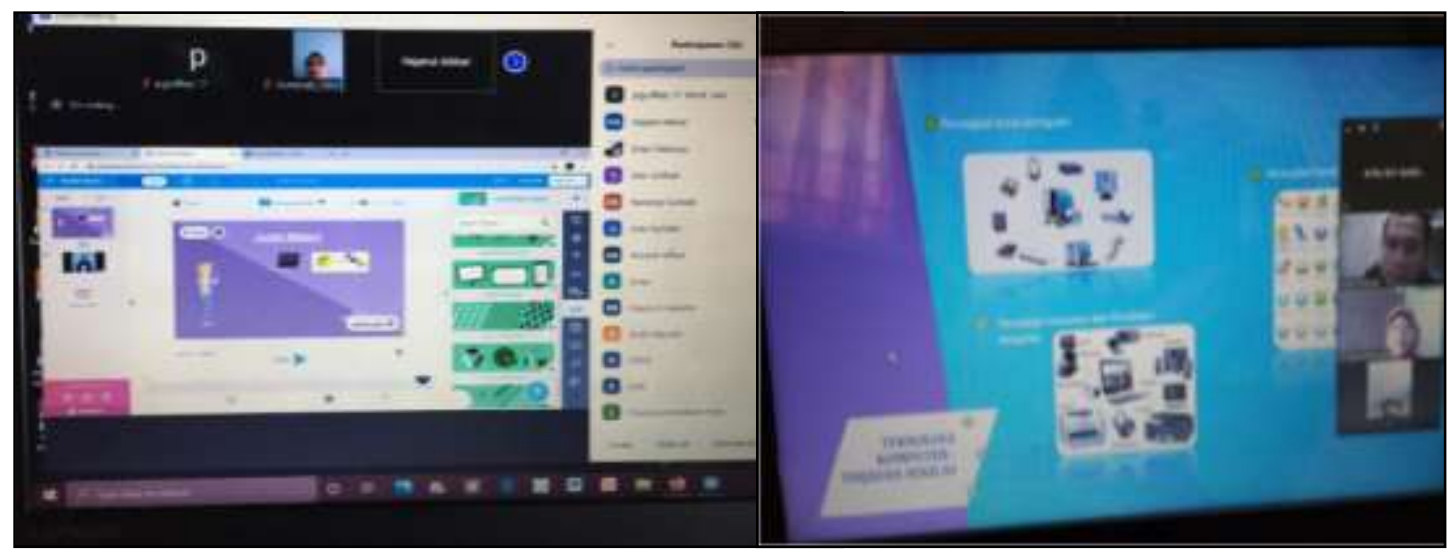

Gambar 2. Materi Webinar Pembuatan Media Pembelajaran Powtoon

3. Pendampingan pembuatan media pembelajaran Powtoon. Kegiatan pendampingan akan dilaksanakan selama 3 (tiga) hari mulai pukul 09.00-12.00 setiap hari. Pelaksanaan pendampingan pembuatan media pembelajaran Powtoon akan dilakukan di tempat masing-masing. Metode penerapan ipteks dilakukan melalui kombinasi tutorial dan praktik langsung. Tahap awal pelatihan mengulas pentingnya media pembelajaran, karena akan memotivasi siswa dalam belajar. Menjelaskan pengertian media pembelajaran Powtoon. Tahap kedua pelatihan adalah melatih mitra dalam membuat media pembelajaran Powtoon, masuk ke akun Powtoon, memilih template, membuat slide materi, memilih animasi, menyimpan materi yang dibuat, mempublikasikannya akan lebih baik. Tahap akhir pelatihan adalah evaluasi. Kegiatan ini ditujukan sebagai indikator keberhasilan pelatihan. Tahap evaluasi pada pelatihan ini berupa evaluasi jangka pendek yang dilakukan di dalam kelas selama pelatihan berlangsung dan dilanjutkan dengan memberikan pengayaan berupa tugas pelatihan bagi peserta agar secara konsisten melengkapi dan menyempurnakan proses pembuatan media pembelajaran Powtoon. Evaluasi dilakukan untuk jangka waktu 3 minggu ke depan, yang dilakukan setiap minggu. Pada minggu keempat tim PKM akan membuat forum pertemuan dengan agenda presentasi oleh mitra. Mitra menyampaikan hasil pembuatan media pembelajaran Powtoon.
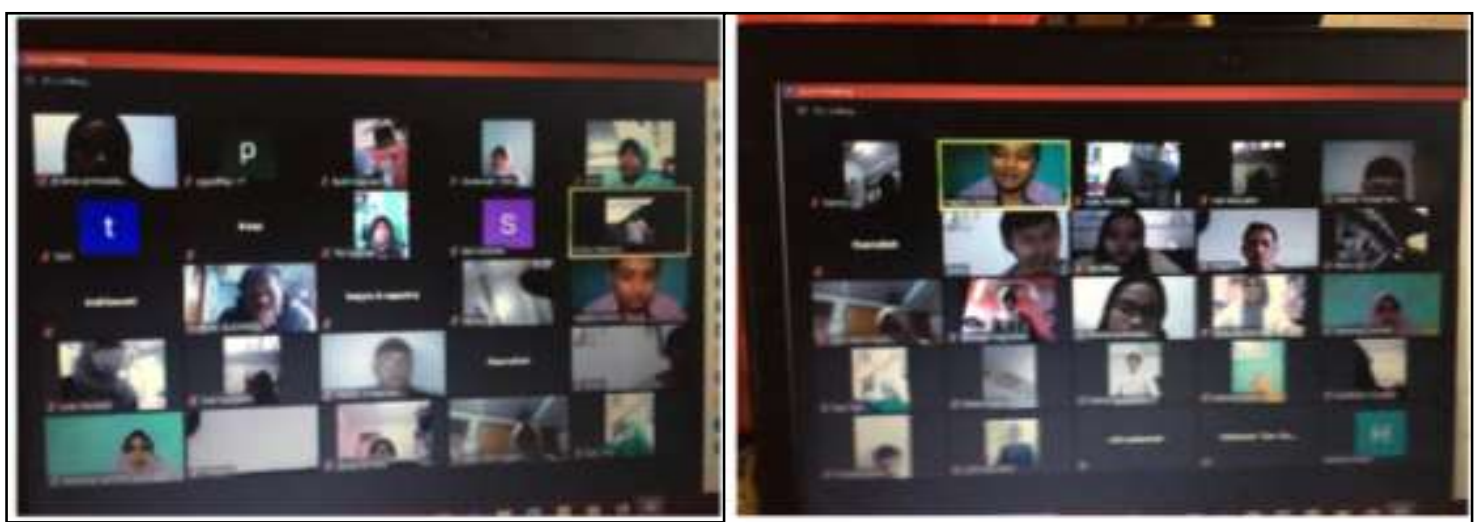

Gambar 3. Pelaksanaan Webinar Pembuatan Media Pembelajaran Powtoon 
Gambar 3 menunjukkan peserta pelaksanaan pendampingan. Seperti diketahui peserta pendampingan berjumlah 34 orang, juga dihadiri oleh bebertapa dosen di lingkungan Pendidikan Guru Sekolah Dasar. Hal ini membuktikan bahwa pembuatan media berbasis teknologi salah satunya Powtoon ini, merupakan materi yang menarik dan penting untuk diaplikasikan dalam pembelajaran baik di seklah dasar maupun perguruan tinggi.

Kegiatan pelatihan dan pendampingan pembuatan media pembelajaran Powtoon ini diikuti oleh 34 orang guru SD Gugus 1 Kota Bogor. Dari 34 orang yang mengikuti pelatihan in $100 \%$ merasa senang, 91,2\% peserta belum pernah mendengar tentang media Powtoon, 97,1\% peserta belum pernah membuat media Powtoon, $82,4 \%$ peserta membuat media pembelajaran Powtoon dan $61,8 \%$ peserta mengumpulkan media pembelajaran Powtoon. Sisanya sebanyak $38,2 \%$ peserta tidak mengumpulkan media powtoon karena berbagai alasan. Alasan peserta yang tidak membuat dan mengumpulkan produk adalah karena belum terbiasa menggunakan komputer dan laptop, belum bisa mengikui langkah-langkah pembuatan media Powtoon, peserta merupakan kepala sekolah jadi tidak mengajar sehingga tidak membuat media Powtoon. Berikut hasil pelatihan dan pendampingan pembuatan media Powtoon.

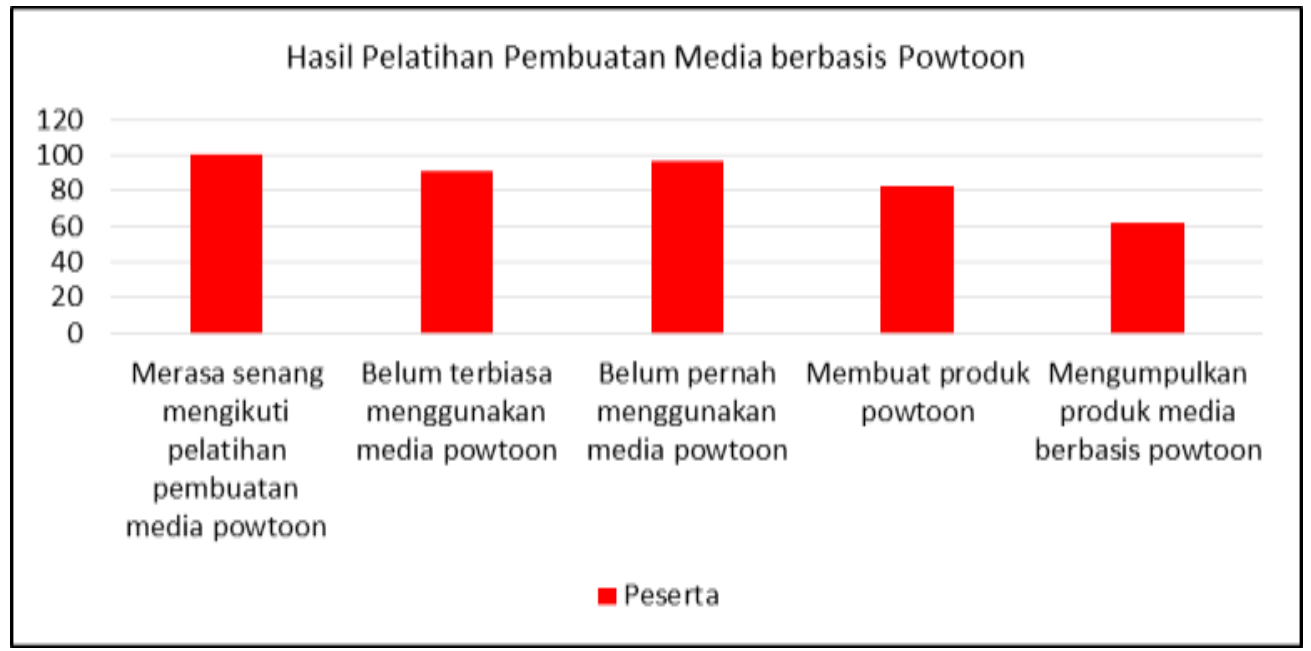

Gambar 4. Hasil Pelatihan dan Pendampingan Pembuatan Media Powtoon

Data yang ditunjukkan pada gambar 4 di atas, membuktikan bahwa pelatihan dan penampingan pembuatan Powtoon menarik minat para pesreta. Hasil pelatihan dan pendampingan menunjukkan angka yang tinggi, jika dilihat dari persentase, maka pelatihan dan pendampingan ini menghasilkan jumlah sekitar $86,5 \%$. Dengan demikian pelatihan pendampingan ini mendapatkan perhatian yang baik atau positif dari peserta.

Berdasarkan peroleh data di atas, dilakukan penilaian media Powtoon dengan kriteria penilaian sebagaimana dalam Tabel 2. Sementara perolehan penilaian menurut kriteria tersebut tersaji dalam gambar 5 . 
Tabel 2. Kriteria Penilaian Media Powtoon

\begin{tabular}{cr}
\hline & Kriteria Penilaian \\
\hline A & $4.1-5,0$ \\
B & $3,1-4,0$ \\
C & $2,1-3,0$ \\
D & $1,1-2,0$ \\
E & $0,0-1,0$ \\
\hline
\end{tabular}

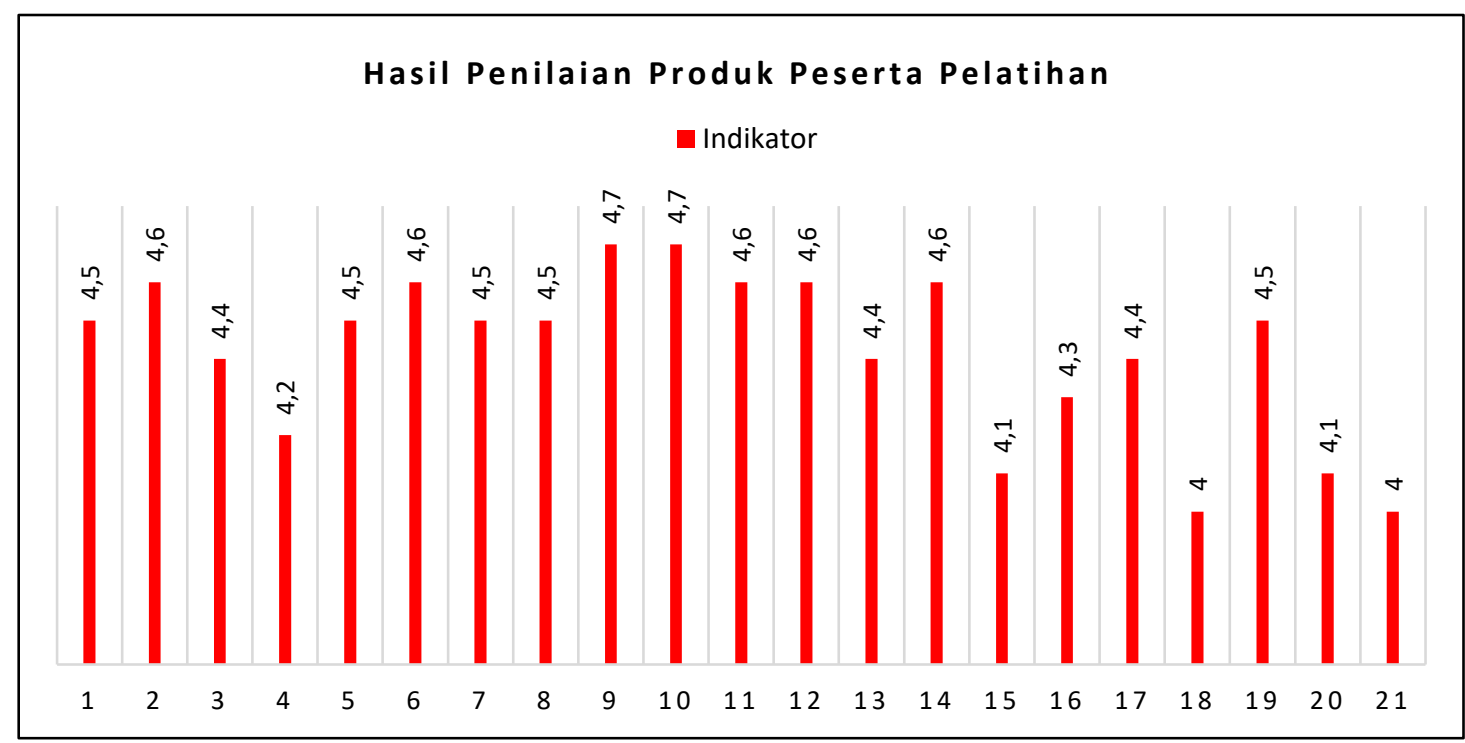

Gambar 5. Nilai Media Powtoon Peserta Pelatihan

Jika dimasukkan ke dalam kriteria penilaian maka sebanyak $17 \%$ yang memperoleh nilai B, sedangkan $83 \%$ nilainya A. Melalui penilaian tersebut dilihat bahwa kekurangan peserta dalam pembuatan media Powtoon adalah dalam hal penampilan, penggunaan huruf, dan kesesuaian indikator dengan materi yang diberikan.

Berdasarkan hasil penilaian di atas, maka dapat dikatakan bahwa pelatihan pendampingan ini sudah cukup berhasil dengan indikator keberhasilan $70 \%$. Keberhasilan tersebut juga dibuktikan oleh sebagian besar peserta pelatihan yang sudah bisa menerapkan media Powtoon sesuai dengan tema dan sub tema yang dipilih oleh setiap peserta.

\section{Kesimpulan}

Kegiatan pelatihan dan pendampingan pembuatan media pembelajaran Powtoon ini diikuti oleh 34 orang guru SD Gugus 1 Kota Bogor selama 3 hari. Respon dari 34 orang yang mengikuti pelatihan ini $100 \%$ merasa senang, $91,2 \%$ peserta belum terbiasa menggunakan media Powtoon, 97,1\% peserta belum pernah membuat media Powtoon, 82,4\% peserta membuat media pembelajaran Powtoon dan $61,8 \%$ peserta mengumpulkan media pembelajaran Powtoon. Sisanya sebanyak $38,2 \%$ peserta tidak mengumpulkan media Powtoon karena berbagai alasan. Kondisi ini diakibatkan kendala jaringan internet yang kurang maksimal, beberapa peserta mengalami kesulitan dalam membuat produk, dan 
belum menguasai IT dengan baik. Penilaian yang dilakukan memperoleh hasil sebanyak $83 \%$ mencapai nilai A dan sebanyak 17\% memperoleh nilai B. Melihat respon dan hasil media Powtoon yang dikumpulkan dapat dikatakan bahwa, pelatihan dan pendampingan pembuatan media Powtoon ini sudah cukup berhasil dengan indikator keberhasilan mencapai lebih dari $70 \%$. Keberhasilan pelatihan juga ditunjukkan dengan media yang dibuat sesuai tema pada kurikulum 2013, buku guru, serta buku siswa.

\section{Ucapan Terima Kasih}

Ucapan terima kasih disampaikan kepada pihak Fakultas Keguruan dan Ilmu Pendidikan (FKIP) Universitas Pakuan yang telah memberikan dukungan pada pelaksanaan pelatihan ini. Kemudian kepada ketua Gugus 1, Bapak Nizar, S.Pd.,M.M., yang telah memberikan fasilitas pelatihan dan juga tidak lupa kepada semua guru peserta pelatihan yang telah mengiktui acara ini sampai selesai.

\section{Referensi}

Andrianti, Y., Susanti, L.R.R. \& Hudaidah. (2016). Pengembangan Media Powtoon Berbasis Audiovisual. Jurnal Criksetra, 5(9), 58-68. DOI: https://doi.org/10.36706/jc.v5i1.4802

Ariyanto, R., Kantun, S., \& Sukidin. (2018). Penggunaan Media Powtoon Untuk Meningkatkan Minat Dan Hasil Belajar Siswa Pada Kompetensi Dasar Mendeskripsikan Pelaku-Pelaku Ekonomi Dalam Sistem Perekonomian Indonesia. Jurnal Pendidikan Ekonomi: Jurnal IImiah IImu Pendidikan, IImu Ekonomi, dan IImu Sosial. 12(1), 122-127 DOI: https://doi.org/10.19184/jpe.v12i1.7622

Awalia, I., Pamungkas, A.S., \& Alamsyah, T.P. (2019) Pengembangan Media Pembelajaran Animasi Powtoon pada Mata Pelajaran Matematika di Kelas IV SD. Kreano Jurnal Matematika Kreatif-Inovatif. 10(1), 49-56. DOI: https://doi.org/10.15294/kreano.v10i1.18534

Fajar, S., Riyana, C., \& Hanoum, N. (2017). Pengaruh Penggunaan Media Powtoon Terhadap Hasil Belajar Siswa Pata Mata Pelajaran Ilmu Pengetahuan Sosial Terpadu. Edutcehnologia, $3(2), 101-114$.

Fitriyani, N. (2019). Pengembangan Media Pembelajaran Audio-Visual Powtoon Tentang Konsep Diri Dalam Bimbingan Kelompok Untuk Peserta Didik Sekolah Dasar. Jurnal Tunas Bangsa. 6(1), 104-114.

Novita, L., Windiyani, T. \& Fazriani, R. (2019). Pengembangan Media Pembelajaran Berbasis ICT Pada Subtema Bersyukur Atas Keberagaman Untuk Siswa Kelas IV Sekolah Dasar. JPPGuseda: Jurnal Pendidikan \& Pengajaran Guru Sekolah Dasar. 2(2), 82-86. DOI: $10.33751 /$ jppguseda.v2i2.1451

Novita, L., Windiyani, T., \& Fauziah, S.S. (2020). Analisis Pemanfaatan Media Pembelajaran Berbasis TIK di Sekolah Dasar Negeri Pengadilan 5 Kota Bogor. JPI (Jurnal Pendidikan Indonesia): Jurnal IImiah Pendidikan. 6(1), 2443-3268. DOI: https://doi.org/10.20961/jpi.v6i1

Nurdiansyah, E., Faisal, E.E, \& Sulkipani. (2018). Pengembangan media pembelajaran berbasis Powtoon pada perkuliahan Pendidikan Kewarganegaraan. Jurnal Civics: Media Kajian Kewarganegaraan. 15(1), 1-8. DOI: https://doi.org/10.21831/jc.v15i1.16875

Ponza, P.J.R., Jampel, I.N., \& Sudarma, I.K. (2018). Pengembangan Media Video Animasi Pada Pembelajaran Siswa Kelas IV di Sekolah Dasar. Jurnal EDUTECH Universitas Pendidikan Ganesha. 6(1), 9-19.

Sudjana, N. (2011). Penilaian Hasil dan Proses Belajar Mengajar. Bandung: Rosda Karya.

Sukmanasa, E., Windiyani, T., \& Novita, L. (2017). Pengembangan Media Pembelajaran Komik Digital Pada Mata Pelajaran Ilmu Pengetahuan Sosial Bagi Siswa Kelas V Sekolah Dasar Di 
Sukmanasa, E., Novita, L., Maesya, A. Pendampingan pembuatan media...

Kota Bogor. Jurnal Pendidikan Sekolah Dasar (JPsd). 3(2), 171-185.

DOI: http://dx.doi.org/10.30870/jpsd.v3i2.2138

Tobamba, E.K., Siswono, E., \& Khaerudin. (2019). Pengaruh Media Pembelajaran Terhadap Hasil Belajar IPS Ditinjau dari Minat Belajar Siswa Sekolah Dasar. Taman Cendekia: Jurnal Pendidikan ke-SD-an. 3(2), 372-380. 